\title{
Peningkatan Ketrampilan Passing Bawah Bolavoli Dengan Mengunakan Metode Bermain Bola Pantul Peserta Ekstrakurikuler Bolavoli Di SMA Negeri 1 Praya Barat Daya
}

\author{
Ali Imran \\ aliimran@ikipmataram.ac.id
}

\begin{abstract}
Abstrak. Penelitian ini menggunakan Quasi Eksperiment One group pretest-postest design dimana dalam penelitian ini tidak ada kelompok pembanding. Populasi penelitian ini adalah seluruh peserta putra yang mengikuti ekstrakurikuler bolavoli yang berjumlah 22 anak, tanpa kelompok pembanding. Maka seluruh peserta putra yang mengikuti ekstrakurikuler digunakan sebagai subjek dalam penelitian. Instrumen yang digunakan adalah tes dan pengukuran menggunakan tes brumbach. Teknik analisis data menggunakan uji normalitas, uji homogenitas dan uji t untuk pengujian hipotesis. Sampel berkorelasi pada taraf signifikasi $5 \%$ atau 0,05. Hasil pengujian menunjukkan bahwa ada pengaruh bermain bola pantul terhadap kemampuan dasar passing bawah. Uji hipotesis menunjukkan nilai t hitung sebesar 7,080 > 2,076 ( t tabel) dan nilai Sign sebesar $(0,000)<0,05$, sehingga hal tersebut menunjukan Ho ditolak dan Ha diterima yang berarti bahwa ada perbedaan yang signifikan terhadap kemampuan dasar passing bawah setelah diberi perlakuan dengan bermain bola pantul. Berdasarkan rata-rata (mean) menunjukkan rerata posttest > pretest. Dari hasil tersebut dapat disimpulkan bahwa ada pengaruh bermain bola pantul yang signifikan terhadap kemampuan dasar passing bawah peserta ekstrakurikuler bolavoli putra SMA Negeri 1 Praya Barat Daya Peningkatan presentase kemampuan passing bawah sebesar 9,88\% dari selisih rerata dibagi rerata pretest dikalikan $100 \%$.
\end{abstract}

Kata Kunci: Bola Pantul, Passing Bawah Dan Bolavoli

\section{PENDAHULUAN}

\section{A. Latar Belakang}

Pendidikan memegang peranan penting dalam pembentukan kualitas sumber daya manusia dan keberhasilan pembangunan. Negara dapat mencapai pembangunan apabila seluruh komponen bangsa memiliki kesamaan tujuan untuk mensukseskan pembangunan, keberhasilan pembangunan dapat optimal ditunjang oleh kualitas sumber daya manusia yang sehat dan bugar. Kesehatan dan kebugaran dapat diwujudkan dengan cara melakukan kegiatan olahraga secara teratur. Dalam hubungannya dengan pembentukan kualitas sumber daya manusia, Pemerintah memberlakukan Pembelajaran Penjasorkes ke dalam setiap jenjang pendidikan SD/MI sampai SMA/SMK.

Pendidikan Jasmani Olahraga dan Kesehatan merupakan salah satu pilar tujuan Pendidikan Nasional (UU. RI. Nomor. 20 tahun
2003), sehingga Pendidikan Jasmani Olahraga dan Kesehatan hukumnya wajib dilaksanakan di setiap jenjang sekolah SD/MI sampai SMA/SMK. Melalui Pendidikan Jasmani Olahraga dan Kesehatan diharapkan dapat mewujudkan bangsa yang sehat baik jasmani maupun rohani dan berkualitas.

Guru dalam pelaksanaan pembelajaran harus berpedoman pada kurikulum, sehingga diharapkan siswa dapat mencapai standar kompetensi. Untuk mencapai tujuan tersebut seorang guru dituntut kreatif dan inovatif dalam kegiatan pembelajaran, baik dalam pengguna alat dan metode pembelajaran sehingga dapat menciptakan suasana pembelajaran yang bermakna dan menyenangkan bagi siswa. Belajar akan lebih bermakna dan menyenangkan bila siswa mengalami serta melakukan. Guru dalam menyampaikan pembelajaran jasmani dituntut dapat mengajarkan berbagai keterampilan gerak dasar, 
teknik dan strategi permainan/olahraga, sportifitas, menanamkan pendidikan karakter (nilai-nilai disiplin, sportifitas, jujur, kerjasama, dan lain-lain) dan pembiasaan pola hidup sehat.

Upaya agar dapat mencapai tujuan tersebut seorang guru dituntut dapat menyajikan pembelajaran menggunakan alat dan metode pembelajaran yang tepat. Alat dan metode pembelajaran memegang peranan penting dalam keberhasilan pembelajaran. Dengan menggunakan alat dan metode pembelajaran yang tepat guru dapat mempermudah penyampaian materi pada siswa. Penggunaan alat diterapkan pada semua mata pelajaran termasuk mata pelajaran Penjasorkes. Pelaksanaan pembelajaran dapat dilakukan dengan latihan-latihan bermain dan bertanding.

Pembelajaran penjasorkes memiliki dua materi yang diberikan kepada siswa, dibedakan menjadi dua kelompok yaitu materi pokok dan materi pilihan. Materi pokok merupakan mata pelajaran yang harus diajarkan pada saat jam pelajaran sekolah. Sedangkan materi pilihan merupakan kegiatan olahraga yang dilakukan di luar jam pelajaran sekolah berupa kegiatan ekstrakurikuler olahraga yang lebih menekankan pada pemahaman, penguasaan kemampuan, dan keterampilan diberbagai cabang olahraga.

Keterampilan teknik dasar passing bawah bolavoli merupakan hal terpenting untuk kegiatan ekstrakurikuler bolavoli. Peserta yang mengikuti ekstrakurikuler bolavoli memiliki keterampilan yang berbeda-beda, karena tidak semua peserta ekstrakurikuler SMA Negeri 1 Sirampog Brebes mengetahui dan mempraktekkan teknik dasar bolavoli dengan baik dan benar. Untuk mengetahui keterampilan yang berbeda-beda tersebut perlu disesuaikan dengan karakteristik peserta ektrakurikuler SMA Negeri 1 Sirampog Brebes yang masih menyukai aktivitas permainan.

Sekolah Menengah Atas yang mengadakan kegiatan ekstrakurikuler bolavoli adalah SMA Negeri 1 Praya Barat Daya Kegiatan ekstrakurikuler bolavoli di SMA Negeri 1 Praya Barat Daya kurang berjalan dengan baik termasuk pembelajaran permainan bolavoli. Dalam kegiatan ekstrakurikuler, teknik dasar permainan bolavoli telah diajarkan dan dilatih dengan cukup baik dan cukup benar tapi belum menunjukkan hasil yang maksimal. Masih banyak peserta ekstrakurikuler yang belum mampu melakukan teknik dasar dengan benar, itu dikarenakan bakat yang dimiliki siswa dalam bermain bolavoli sangat kurang. Keterampilan teknik dasar permainan bolavoli yang belum baik akan berpengaruh pada kualitas permainan yang rendah. Pemberian metode melatih ekstrakurikuler bolavoli dirasa masih kurang adanya variasi pemberian metode yang menarik yang membuat peserta lebih antusias lagi dalam mengikuti kegiatan ekstrakurikuler bolavoli.

Banyak faktor yang mempengaruhi keterampilan teknik dasar bolavoli. Rendahnya keterampilan teknik dasar passing bawah permainan bolavoli tersebut perlu ditelusuri faktor penyebabnya, apakah karena penguasaan teknik dasarnya yang kurang baik, kemampuan fisik yang tidak mendukung atau metode melatih yang kurang efektif dan lain sebagainya. Kondisi yang demikian seseorang guru pendidikan jasmani dan pelatih harus mampu mengevaluasi dari semua faktor baik dari pihak guru atau pelatih sendiri maupun dari pihak peserta yang mengikuti ekstrakurikuler bolavoli.

Berdasarkan uraian di atas, maka penulis berminat untuk melakukan penelitian eksperimen yang akan penulis beri judul "Peningkatan Keterampilan Passing Bawah Bolavoli dengan Menggunakan Metode Bermain Bola Pantul Peserta Ekstrakurikuler Bolavoli di SMA Negeri 1 Praya Barat Daya" KAJIAN PUSTAKA

\section{Hakikat Keterampilan}

Terampil diartikan sebagai suatu perbuatan atau tugas dan sebagai indikator dari suatu tingkat kemahiran. Suatu keterampilan yang dipandang sebagai aktivitas gerak/suatu tugas akan terdiri dari sejumlah respon gerak dan persepsi yang didapat melalui belajar untuk tujuan tertentu. Menurut Singer (Amung Ma'mun 1999: 61), keterampilan adalah derajat 
keberhasilan yang konsisten dalam mencapai suatu tujuan dengan efektif dan efisien ditentukan oleh kecepatan, ketepatan, bentuk dan kemampuan menyesuaikan diri. Sedangkan menurut Arma Abdoellah (1985: 3) seseorang dikatakan sangat terampil bila ia bergerak secara efisien dan efektif atau bila ia nampak mempunyai potensi yang baik untuk melaksanakan satu gerak khusus. Keterampilan seseorang yang tergambarkan dalam kemampuan menyelesaikan tugas gerak tertentu dapat terlihat mutunya dari seberapa jauh orang tersebut mampu menampilkan tugas yang diberikan dengan tingkat keberhasilan tertentu.

Suatu keterampilan baru dapat diperoleh atau dikuasai, apabila dipelajari atau dilatihkan dan dilakukan secara terus menerus dalam periode waktu tertentu. Menurut Sage dalam R. Hari Amirullah (2003: 17), semakin tinggi tingkat keberhasilan dalam melaksanakan tugas gerak maka semakin baik keterampilannya.

2. Hakikat Permainan Bolavoli a. Pengertian Permainan Bolavoli

Permainan bolavoli sendiri merupakan jenis permainan yang menggunakan bola besar. Bolavoli adalah permainan di atas lapangan persegi empat yang lebarnya $900 \mathrm{~cm}$ dan panjangnya 1800 $\mathrm{cm}$, dibatasi oleh garis-garis selebar $5 \mathrm{~cm}$, di tengah-tengahnya dipasang jaring yang lebarnya $900 \mathrm{~cm}$, terbentang kuat dan sampai pada ketinggian $243 \mathrm{~cm}$ dari bawah (khusus putra) dan untuk anak putri kurang lebih 224 cm (Bonnie Robinson, 1997 :12).

Berdasarkan pada macam teknik dasar passing dalam permainan bola voli, maka teknik passing dibedakan meliputi teknik passing atas dan teknik passing bawah.

\section{a) Passing atas}

Cara melakukan teknik passing atas adalah jari-jari tangan terbuka lebar dan kedua tangan membentuk mangkuk hanpir saling berhadapan. Sebelum menyentuh bola, lutut sedikit ditekuk hingga berada di muka setinggi hidung. Sudut antara sikut dan badan kurang lebih 45 derajat. Bola disentuhkan dengan cara meluruskan kedua kaki dengan lengan.

Menurut Nuril Ahmadi (2007 : 2627) memainkan bola dengan teknik passing atas dapat dilakukan dengan berbagai variasi yaitu antara lain: 1) passing atas ke arah belakang lewat atas kepala, 2) passing atas ke arah samping pemain, 3) passing atas sambil melompat ke atas, 4) passing sambil menjatuhkan diri kesamping, 5) passing atas sambil menjatuhkan diri ke belakang.

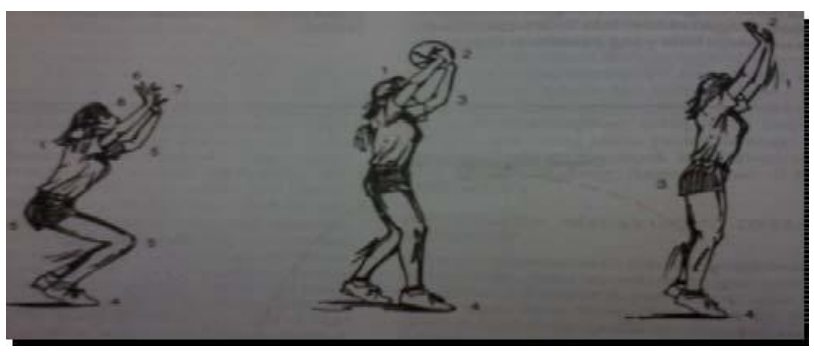

Gambar 2. Rangkaian Gerakan Passing Atas. (Barbara L Viera \& Bonnie J Ferguson 2000:54)

b) Passing bawah

Menurut Barbara L Viera \& Bonnie J Ferguson (2000:19) passing bawah atau operan lengan bawah merupakan teknik dasar bolavoli yang harus di pelajari lebih tegasnya

Barbara \& Bonnie mengatakan bahwa "operan ini biasanya menjadi teknik pertama yang digunakan tim bila tidak memegang servis. Operan ini digunakan untuk menerima servis, menerima spike, memukul bola setinggi pinggang ke bawah dan memukul bola yang terpantul di net”.

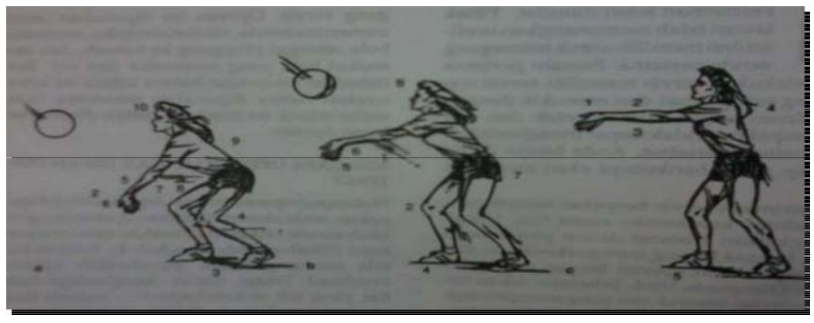

Gambar 3. Rangkaian Gerakan Passing Bawah. Barbara L Viera \& Bonnie J Ferguson 2000:20) 


\section{3) Smash}

Smash merupakan pukulan yang utama dalam penyerangan dalam usaha mencapai kemenangan (M. Yunus, 1992: 156). Sedangkan menurut Nuril Ahmadi (2007: 31) smash merupakan pukulan bola yang keras dari atas ke bawah, jalannya menukik. Smash merupakan bentuk serangan yang paling banyak dipergunakan dalam upaya memperoleh nilai oleh suatu tim.

\section{METODE PENELITIAN}

\section{A. Desain Penelitian}

Penelitian ini merupakan Jenis penelitian eksperimen, artinya penelitian bertujuan untuk mencari hubungan sebabakibat. Penelitian eksperimen merupakan penelitian yang dimaksudkan untuk mengetahui ada tidaknya akibat dari "sesuatu" yang dikenakan pada subjek selidik (Suharsimi, 1989:257). Desain penelitian yang digunakan ialah "Quasi One-Gruop Pretest-Posttest Design" (Suharsimi Arikunto, 2010: 124). Artinya dalam desain terdapat satu subyek yang diberi perlakuan (treatment) dengan dua kali pengukuran yaitu sebelum eksperimen dan sesudah eksperimen atau tes awal (pre-test) dan tes akhir (post-test). Secara skematis digambarkan seperti berikut :

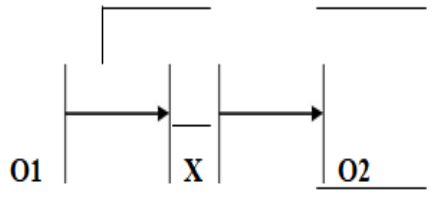

Gambar 7. Desain Penelitian (One-Group Pretest-Posttest Design)

(Suharsimi Arikunto 2010: 124)

Keterangan :

$\mathrm{O} 1$ : pre-test

$\mathrm{X}$ : treatment

$\mathrm{O}_{2}$ : post-test

1. Dalam penelitian ini tes dilakukan sebanyak dua kali yaitu sebelum eksperimen dan sesudah eksperimen. Perbedaan antara pretest $\left(\mathrm{O}_{1}\right)$ dan post-test $\left(\mathrm{O}_{2}\right)$ ini diasumsikan merupakan efek dari eksperimen atau treatment. Metode bermain bola pantul yang diberikan dalam penelitian ini adalah bermain bola pantul yang dipergunakan untuk mencapai penguasaan gerakangerakan passing bawah yang baik.

2. Passing bawah adalah suatu proses yang melahirkan keaktifan jasmani dan dibuktikan dalam praktik dengan menyelesaikan tugas dalam cabang permainan bolavoli, dalam hal ini adalah teknik passing bawah. Dalam penelitian ini teknik passing bawah akan diukur dengan menggunakan tes Brumbach forearms pass wall-volley test.

\section{Populasi dan Sampel Penelitian}

Menurut Suharsimi Arikunto (2010: 173) populasi adalah keseluruhan subjek penelitian. Sedangkan menurut Sugiyono (2010: 61) bahwa yang dimaksud dengan populasi adalah wilayah generalisasi yang terdiri atas objek/ subjek yang mempuyai kualitas dan karakteristik tertentu yang ditetapkan oleh peneliti untuk dipelajari dan kemudian ditarik kesimpulan. Populasi yang digunakan dalam penelitian ini adalah peserta ekstrakurikuler bolavoli di SMA Negeri 1 Praya Barat Daya yang berjumlah 32 siswa yang terdiri dari 22 peserta putra dan 10 peserta putri.

Sedangkan sampel menurut Suharsimi Arikunto (2010: 174) sampel adalah sebagian atau wakil populasi yang diteliti. Sampel dalam penelitian ini adalah peserta ektrakurikuler bolavoli putra di SMA N 1 Praya Barat Daya yang berjumlah 22 siswa. Sehingga penelitian ini adalah penelitian sampel karena menggunakan peserta ektrakurikuler putra saja.

\section{Waktu dan Tempat Penelitian}

1. Waktu Penelitian

Penelitian ini dilakukan selama 3 bulan

yaitu dari bulan Februari sampai April 2019.

2. Tempat Penelitian

Penelitian ini dilakukan di SMA Negeri 1 Praya Barat Daya. Beralamatkan di Jalan Raya Darek-Ungga 


\section{E. Instrumen dan Teknik Pengumpulan Data}

1. Instrumen Penelitian

Instrumen penelitian adalah alat atau fasilitas yang digunakan oleh peneliti dalam mengumpulkan data agar pekerjaannya lebih mudah dan hasilnya lebih baik dalam arti lebih cermat, lengkap dan sistematis sehingga lebih mudah diolah (Suharsimi Arikunto, 2002 : 136). Dalam penelitian ini digunakan instrumen tes sebagai alat untuk mengumpulkan data. Tes yang digunakan yaitu:

Pre-test (Brumbach forearms pass wallvolley test) dan post test. 1 ) Tujuan

Untuk $m$ engukur $\mathrm{k}$ emampuan dan kecepatan dalam melakukan passing $\mathrm{b}$ awah denga $n$ memvoli ke dinding.

2 ) Alat perlengkapan

Dinding yang rata da $\mathrm{n}$ halus dengan garis sa saran seleb ar 2,54 cm, setinggi 2,44 m $\mathrm{d}$ ari lantai. Selain itu, stop watch, blangko penilaian, dan bola voli juga digu nakan dala $\mathrm{m}$ setiap tes.

3 ) Petunjuk pelaksanaa n

Testi de ngan bolav oli di tangan berdiri $m$ enghadap ke dinding sasaran. Setelah ada aba-aba "ya" bola dila mbungkan ke dinding sasaran. Bola dipantul-pantulkan dengan menggunakan passing bawah sebanyakbanyaknya dan di atas garis 2.44 meter.

4) Penilaian

Skor diambil dari jumlah pantulan bola yang sah selama satu menit. Setiap peserta mendapatkan tiga kali percobaan. Skor akhir diambil dari jumlah pantulan rata-rata dua kali percobaan terbaik. Lemparan tidak masuk dalam hitungan skor.

5) Reliabilitas

Borenvik (1969) dalam Cox Richard H (1980: 102) melaporkan bahwa reliabilitas setinggi 0,896 .

6) Objektivitas

Tak seorangpun melaporkan koefisien objektivitas namun dianggap tinggi karena sifat tugas.

\section{7) Validitas}

Cox (1977) dalam Cox Richard H (1980: 102) melaporkan koefisien validitasnya 0,80 dengan keterampilan passing dalam situasi permainan sebagai kriteria.

2. Teknik Pengumpulan Data

Teknik pengumpulan data dalam penelitian ini dengan menggunakan tes. Tes yang digunakan dalam penelitian ini adalah Brumbach forearms pass wall-volley test. Proses penelitian ini diawali dengan memberikan pemanasan kepada siswa. Setelah itu diberikan petunjuk bagaimana melakukan tes Brumpach agar siswa paham

\section{F. Teknik Analisis Data}

Pada penelitian ini teknik analisis data yang digunakan adalah teknik analisis statistik menggunakan uji-t dengan bantuan analisis statistik data SPSS versi 16.0. Analisis data bertujuan untuk mengetahui jawaban pertanyaan dalam penelitian. Sebelum diadakan pengujian dalam uji-t, perlu dilakukan uji prasyarat terlebih dahulu. Uji prasyarat dimaksudkan untuk mengetahui apakah data yang dianalisis memenuhi persyaratan untuk dilakukan analisis data dan pengujian hipotesis. Uji prasyarat yang dilakukan adalah uji normalitas dengan uji Kolmogorov-Smirnov dan uji homogenitas dengan uji Lavene Statistic.

Setelah semua uji prasyarat analisis terpenuhi, langkah berikutnya adalah analisis dengan uji-t. Uji-t untuk mengetahui ada atau tidaknya peningkatan keterampilan passing bawah bolavoli siswa setelah diberikan perlakuan.

\section{Uji Prasyarat Analisis}

a. Uji Normalitas

Uji normalitas dimaksudkan untuk mengetahui normal atau tidaknya distribusi data yang diperoleh. Uji normalitas ini menggunakan teknik Kolmogorov-Smirnov dilakukan dengan bantuan program komputer SPSS versi 16.0. Kaidah yang digunakan untuk mengetahui normal atau tidaknya suatu sebaran adalah jika $\mathrm{p}>0,05$ maka normal, sebaliknya jika $\mathrm{p}<0,05$ sebaran dikatakan tidak normal. 


\section{b. Uji Homogenitas}

Uji homogenitas dimaksudkan untuk mengetahui apakah kelompok data berasal dari populasi yang memiliki varians yang sama. Pengujian homogenitas menggunakan One-Way ANOVA dilakukan dengan bantuan progam komputer SPSS versi 16.0. Kriteria pengambilan keputusan adalah apabila nilai sig. $>0,05$ atau $\mathrm{F}$ hitung < $\mathrm{F}$ tabel, berarti sampel tersebut homogen. Langkah-langkah uji homogenitas dengan One-Way ANOVA adalah sebagai berikut:

1) Masukkan data pada SPSS

2) Untuk melakukan analisis klik Analyze >>

\section{Compare Mean >>}

One-Way Anova

3) Masukkan variabel hasil tes siswa pada kotak Dependent List dan variabel jenis tes ke kotak Factor.

4) Klik Option >> aktifkan Homogeity of Variance test $>>$ Continue

5) Lalu klik $\boldsymbol{O K}$.

\section{Analisis Data}

Analisis data ditujukan untuk menguji hipotesis penelitian, yaitu Ada peningkatan keterampilan dasar passing bawah bolavoli dengan menggunakan metode bermain bola pantul peserta putra di SMA Negeri 1 Praya Barat Daya yang mengikuti ekstrakurikuler bolavoli.Teknik analisis yang digunakan untuk menguji apakah skor rata-rata dari pretestdan kelompok postest memiliki perbedaan yang signifikan. Data dikatakan signifikan apabila $\left(t_{h}\right)$ lebih besar dari $t_{\text {tabel }}\left(t_{t}\right)$ dan nilai plebih kecil dari 0,05. Peningkatan skor rata-rata kedua kelompok terlihat dari perbedaan skor rata-rata tes awal dan tes akhir. Seluruh perhitungan uji-t dilakukan dengan bantuan SPSS seri 13,0.

Rangkuman hasil uji-t data pretest passing bawah dan postest passing bawah disajikan dalam tabel berikut.

\section{Tabel 19.Rangkuman Hasil $\boldsymbol{U} \boldsymbol{j i}$ - $\boldsymbol{t}$}

\begin{tabular}{|l|c|c|c|c|l|}
\hline Sumber & $t_{h}$ & $t_{t}$ & $D b$ & $p$ & Keterangan \\
\hline Data pretest & 7,080 & 2,076 & 21 & 0,000 & $t_{h}>t_{t}=$ signifikan \\
\hline passing bawah & & & & & $7,080>2,055=$ signifikan \\
dan postest & & & & & $p<0,05=$ signifikan \\
\hline passing bawah & & & & & $0,000<0,05=$ signifikan \\
\hline
\end{tabular}

Dari tabel diatas dapat diketahui besarnya $t_{\text {hitung }}$ 7,080dengan $\mathrm{db}$ 21. Kemudian skor $\mathrm{t}_{\text {hitung }}$ tersebut dikonsultasikan dengan $t_{\text {tabel }}$ pada taraf signifikansi 5\% dan db 21 adalah 2,076; hal itu menunjukkan bahwa skor $t_{\text {hitung }}$ lebih besar dari skor $\mathrm{t}_{\text {tabel }}\left(\mathrm{t}_{\mathrm{h}}: 7,080>\mathrm{t}_{\mathrm{t}}: 2,076\right)$. Dari tabel diketahui nilai $p=0,000$; hal ini menunjukkan bahwa nilai plebih kecil 0,05. Dengan demikian hasil uji-t tersebut menunjukkan "Ada peningkatan keterampilan

dasar passing bawah bolavoli dengan menggunakan metode bermain bola pantul peserta putra di SMA Negeri 1 Praya Barat Daya yang mengikuti ekstrakurikuler bolavoli". Besarnya perubahan kemampuan passing bawah tersebut dapat dilihat dari perbedaan nilai rata-rata yaitu sebesar 2,61 lebih banyak hasil setelah diberikan latihan dibandingkan sebelum diberikan latihan.

Secara spesifik hasil perlakuan dapat diketahui melalui penghitungan prosentase peningkatanya sebagai berikut:

Tabel. Hasil Prosentase Peningkatan

\begin{tabular}{|r|r|r|}
\hline Mean Difference & Mean Pre-Test & Peningkatan(\%) \\
\hline 2,61364 & 29,4091 & 9,87976 \\
\hline
\end{tabular}

Berdasarkan tabel tersebut dapat diketahui bahwa peningkatan kemampuan passing bawah peserta putra di SMA Negeri 1 Praya Barat Daya 9,88 \% setelah diberikan latihan bermain bola pantul

PEMBAHASAN

Penelitian ini bertujuan untuk mengetahui seberapa besar peningkatan keterampilan teknik dasar permainan bolavoli jika diberikan dengan metode bermain bola pantul pada pesertaputra yang mengikuti ekstrakurikuler di SMA Negeri 1 Praya Barat Daya

Berdasarkan hasil penelitian diketahui bahwa besarnya thitung 7,080dengan db 21 . Kemudian skor $t_{\text {hitung }}$ tersebut dikonsultasikan dengan $\mathrm{t}_{\text {tabel }}$ pada taraf signifikansi $5 \%$ dan $\mathrm{db}$ 21 adalah 2,076; hal itu menunjukkan bahwa skor $\mathrm{t}_{\text {hitung }}$ lebih besar dari skor $\mathrm{t}_{\text {tabel }}\left(\mathrm{t}_{\mathrm{h}}: 7,080>\right.$ $\left.\mathrm{t}_{\mathrm{t}}: 2,076\right)$. Dari table diketahui nilai $p=0,000$; 
hal ini menunjukkan bahwa nilai plebih kecil 0,05 . Dengan demikian hasil uji-t tersebut menunjukkan "Ada peningkatan keterampilan dasar passing bawah bolavoli dengan menggunakan metode bermain bola pantul peserta putra di SMA Negeri 1 Sirampog Brebes yang mengikuti ekstrakurikuler bolavoli". Besarnya perubahan kemampuan passing bawah tersebut dapat dilihat dari perbedaan nilai rata-rata yaitu sebesar 2,61 lebih banyak hasil setelah diberikan latihan dibandingkan sebelum diberikan latihan. Peningkatan kemampuan passing bawah peserta putra di SMA Negeri 1 praya Barat Daya sebesar 9,88\% setelah diberikan latihan bermain bola pantul.

Passing bawah merupakan teknik permainan bolavoli yang sangat penting untuk dikuasai oleh seorang pemain bolavoli serta memiliki fungsi yang banyak. Menurut Barbara L. Viera (2004 : 19) Operan lengan bawah merupakan teknik dasar bolavoli yang harus dipelajari. Operan ini bisanya menjadi teknik pertama yang digunakan untuk menerima servis, menerima spike, memukul bola setinggi pinggang ke bawah dan memukul bola memantul dari net.

Teknik passing bawah adalah teknik penerimaan bola dengan menggunakan kedua tangan, yaitu perkenaan bola pada pada kedua lengan bawah yang bertujuan untuk mengoperkan bola kepada teman seregunya untuk dimainkan di lapangan sendiri atau sebagai awal untuk melakukan serangan. Teknik passing bawah merupakan satu-satunya cara untuk menerima servis yang sulit atas serangan lawan, karena dengan passing bawah

\section{Kesimpulan}

Berdasarkan analisis data, pengujian hipotesis dan pembahasan yang telah dilakukan dapat dikemukanan beberapa kesimpulan sebagai berikut:

1. Ada peningkatan keterampilan teknik dasar passing bawah permainan bolavoli setelah diberikan dengan metode bermain bola pantul pada peserta putra yang mengikuti ekstrakurikuler di SMA Negeri 1 Praya Barat Daya, hal ini ditunjukkan dari nilai $t_{\text {hitung }}$ lebih besar dari skor $t_{\text {tabel }}\left(t_{h}: 7,080>t_{t}: 2,076\right)$ dan nilai $p=0,000$ lebih kecil 0,05 . Besarnya peningkatan keterampilan teknik dasar permainan bolavoli jika diberikan dengan metode bermain bola pantul pada peserta putra yang mengikuti ekstrakurikuler di SMA Negeri 1 Praya Barat Daya, sebesar 9,88\% dengan perbedaan nilai rata-rata yaitu sebesar 2,61 lebih banyak hasil setelah diberikan latihan dibandingkan sebelum diberikan latihan

\section{DAFTAR PUSTAKA}

Agus Mahendra. (2003). Falsafah Pendidikan Jasmani.

Diakses dari http://www.ditplb.or.id/profile.php?id=6 $\underline{5}$ pada tanggal 25 Oktober 2011, pukul 16.00 WIB.

Aip Syarifudin dan Muhadi. (1992). Pendidikan Jasmani dan Kesehatan.

Amung Ma'mun dan Yuda. (2000). Perkembangan Gerak dan Belajar Gerak. Jakarta : Depdikbud

Anung Suprayogi. (2011). Pengaruh Pembelajaran Model Bermain terhadap Kemampuan Passing Siswa Peserta Ekstrakurikuler dalam Permainan Bola Voli di SMK Ganesa Satria 4 Kedu Temanggung. Skripsi. Yogyakarta : FIK UNY.

Asep Kurnia Nenggala. (2006). Pendidikan Jasmani, Olahraga dan Kesehatan. Grafindo Media Pratama.

Astopo. (2007). Pengaruh Pembelajaran Bolavoli Suhadi terhadap Ketrampilan Bolavoli Siswa Putri di SMP Negeri 3 Pleret Bantul. Skripsi. Yogyakarta: FIK UNY.

Barbara L. Viera \& Bonnie J. Freguson. (2004). Bolavoli Tingkat Pemula. Jakarta: PT. Rajagrafindo Persada.

Beutelstahl Dieter. (1986). Belajar Bermain Volley. Bandung: Pioner Jaya. 
Bonnie Robinson (1993). Bolavoli. Semarang:

Dahara Prize.

Bulman, George.(1995). Volleyball Play the game. Great Britain: Blandford. Gramedia.

Cox Richard H. (1980). Teaching Volleyball. USA. Burgess Publishing Company

Durwachter G. (1986). Bola Volley Belajar dan Berlatih Sambuil Bermain. Jakarta: PT Gramedia Jakarta.

Engkos Kosasih. (1985). Olahraga Teknik dan Program Latihan. Jakarta : CV.

Akademika Pressindo.

Hari Amirulloh. R. (2003). Alat Evaluasi Keterampilan Bermain Bola Basket : Jurnal Nasional Pendidikan Jasmani dan Ilmu Keolahragaan. Jakarta : Depdiknas. 